\title{
薬液により固結した砂の粘着力とダイレイタンシーについて COHESION AND DILATANCY OF SANDS STABILIZED BY CHEMICAL GROUT
}

\author{
森麟*.田村昌仁** \\ By Akira MORI and Masahito TAMURA
}

\begin{abstract}
To elucidate the mechanical behaviour of sands strengthened by cementing materials, we investigate the relation between cohesion (i. e. cohesive bonds made by silicate gel) and dilatancy of stabilized sand in shearing process. In experiments, triaxial drained tests, triaxial undrained tests, and constant mean principal effective stress tests were performed. The conclusions are summarised as follows ;

1) Although the dilatancy initiation of stabilized sands in shearing process is delayed by cohesion as compared with unstabilized sands, the dilatancy is much larger than that of unstabilized sands when the axial deformation increases to a certain degree.

2) Cohesion would be uniquely related to $\varepsilon_{v d}$ (volumetric strain caused by shear stress increment only) rather than the shear strain, irrespective of the confined stress and drain or undrained condition.
\end{abstract}

\section{1. まえがき}

粘着力を有さない未固結な砂が, 結合材 (ゲル)によ り固結されると，未固結な状態において発揮されるダイ レイタンシーを含めた摩擦抵抗に加えて, ゲル自身の強 度に基づく粘着力が固結砂の強度に影響を及ぼすことに なる. 未固結な砂の強度・変形特性に関する研究は, 古 くより盛んに行われており，ストレス・ダイレイタン シ一式に基づく構成式もいくつか提案されている ${ }^{1), 2)}$. しかし, 粘着力を有した砂の力学的特性に注目した研究 は少なく不明な点が多い. 砂粒子間隙を満たしているゲ ルは，そのゲル強度による粘着力を砂に与えているだけ ではなく砂粒子間のかみ合わせに起因するダイレイタン シ一の関係にも大きな影響を及ぼすと考えなければなら ない. そして, 固結による強度増加作用としての粘着力 とダイレイタンシーの影響は, 結合材自身の強度によっ ても異なると思われる. 強い結合材の場合には, 強度増 加作用は粘着力が支配的となるが, 弱い結合材の場合に は, 粘着力, ダイレイタンシーおよびダイレイタンシー に基づく負圧が発生することになり, 強度に占めるこれ

* 正会員 工博 早稲田大学教授 理工学部土木工学科 ( ₹160 新宿区大久保 3-4-1)

** 学生会員 工修 早稲田大学大学院博士後期課程 (同上)
ら三成分の大きさが重要となろう.

実際問題として, 弱い結合材による固結砂を考慮する 必要性は, 薬液注入の場合などにおいて生じる. 薬液注 入工法は, 止水, 強度増加を目的とした地盤改良工法の 1 つであり, シールド工事や開削工事等における沈下, 変形防止対策として用いられている. 本研究は, 浸透注 入により強化された粘着力を有する固結砂を対象とし て, その強度特性を調査・研究したものである. 現時点 において, 最も多く使用されている薬液は水ガラス系の ものであるため, この薬液を用いて砂に粘着力を与える ことにした. 水ガラス系固結砂の強度特性は, 変形速度 や排水・非排水条件により異なり,ダイレイタンシーに 起因する間腙水の負圧の影響も考慮しなければならな い. しかし, この固結砂では, 結合材自身の強度が小さ いので, 正確に測定することが困難な負圧の影響が大き くなり, 粘着力の影響を詳しく調べることができない. 今回の研究は, 弱い結合材で固結した砂の強度に及ぼす 粘着力とダイレイタンシーの影響を明らかにすることを 目的としているため, 負圧が発生しない条件のもとで実 験を行うことにした。 なお, 負圧の影響については, 別 途報告する ${ }^{3)}$.

実験においては, 固結砂の三軸圧縮排水試験, 三軸圧 縮非排水試験, 平均有効主応力一定試験を行っている. 


\section{2. 従来の研究}

固結砂の三軸圧縮試験によって, 強度定数である粘着 力成分と摩擦角を求めている研究は数多く行われてい $3^{4) \sim 10)}$. 摩擦角 $\phi$ は, 未固結なものと等しく, 粘着力 成分がゲルにより発揮されて強度増加が期待できるとい う報告4),6) が多いが，一方では，摩擦角が固結させるこ とにより低下することも指摘されている ${ }^{8), 9)}$. 従来の研 究では, 排水条件, 変形速度等が明確でないために上記 のような結果が得られたと考えられ，固結砂の強度発現 機構については，現時点においても明らかでない部分が 多い.

粘着力成分は，一般にモールの破壊包絡線より決定さ れる粘着力 $c$ で評価されているが，この大きさは必ず しもゲルによる粒子間の結合力を意味するわけではな い. 水ガラス系固結砂の透水係数は $K=10^{-5 \sim-7}(\mathrm{~cm} / \mathrm{s})$ となるため, 試験条件としては, 通常非排水せん断が想 定されている. しかし，拘束圧が十分大きくない限り， 完全な非排水状態が得られず，ダイレイタンシーに基づ く負圧が発生することになる。したがって, 粘着力 $c$ は負圧の影響を含んでいると考えなければならない，今 回の研究では，有効応力表示における固結砂の強度特性 を明らかにすることが目的であるため，このような負圧 が発生しない条件で実験を行うことにした.

春山らは ${ }^{11,12}$ 非粘性材料であるシラスの $\mathrm{CD}$ 試験を行 い，見掛けの粘着力 $c_{d}$ は，インターロッキングを含む ダイレイタンシーにより生じたものであり, Rowe のダ イレイタンシー補正で求められる粘着力はゼロになると いうことを指摘している. 西田は ${ }^{13)}$ ，このような $c_{d}$ と ダイレイタンシーの関係がまさ土においても見受けられ ることを述べている．固結砂の粘着力は，シラスやまさ 土の場合と同様に，ダイレイタンシーにより発揮される ことも考えられるので，固結砂の強度に及ぼすダイレイ タンシーの影響を考慮する必要がある.

固結砂亡構造的に等しい粒子充填型のエラストマ- ${ }^{14)}$ や結合力が高度に発達した岩石 ${ }^{15}$ においては, ダイレイ タンシ一の発生は, 結合力の破壊とみなされている. 著 者らは，固結砂のせん断過程における構造変化を調べる ため透水係数の変化に注目した実験を行った結果 ${ }^{16)}$, 破 壊時における透水係数は，せん断前の 100 倍程度増加す る場合があり，破壊時にはゲル強度に基づく粘着力がほ とんど消失していることを明らかにした，Krizek らは17) 等せん断ひずみ線より，せん断過程において発揮されて いる粘着力成分を調べており，粘着力はせん断ひずみの 小さい段階で最大になることを指摘している．したがっ て, ゲル強度に基づく粘着力は, 必ずしも破壊時におい て, 最大限に発揮されているわけではない.
また, 足立らは ${ }^{18)}$, 堆積軟岩の力学的特性を調べた結 果, その強度特性は, 応力条件のみに関係しておらず, ひずみも考虑しなければならないことを指摘しており， 粘着力を有する土の強度特性を明らかにするためには, その粘着力とひずみの関係が重要になると思われる.

本研究は, 上記の点を考慮して, 固結砂の強度に及ぼ す粘着力とダイレイタンシーの影響について検討したも のであり, 粘着力 (ゲル) の破壊と変形量 (せん断ひずみ, 体積ひずみ) の関係についても考察を加えている.

\section{3. 試料および装置}

表一1,2に, 使用した砂, 薬液を示す. 表一2のゲル強 度 $c_{0}$ は, 引抜き試験により求めたホモゲル（薬液のみ の固結物）のせん断強度である。この強度に及ぼす変形 速度の影響はあまり生じないことを確認している。

固結砂の試料作製方法は, モールド内に所定の割合で 配合されたまだゲル化していない薬液を流し込み，上部 より砂を落下させてそのまま固めることにした。 なお試 料の養生方法は, すべて 1 日水中養生である.

三軸圧縮排水試験, 三軸圧縮非排水試験は，ひずみ速 度 $\dot{\varepsilon}_{1}=0.07 \% / \mathrm{min}$ で行っている.この速度で, 排水試 験が成立しているかどうか確認するため, 供試体の下端 より間隙水圧を与えて，せん断中の供試体上端（上端は 非排水条件）での間隙水圧を測定したところ, 下端の水 に等しく, 変形中ほとんビ変化がみられないので, 供試 体内部の間隙水圧は変形中一定であると思われる. 実際 の試験が両端排水としたことを考慮すると，この速度で 十分に排水状態が成立しているものと考えることができ る. 非排水試験では，キャビテーションが発生しないよ うに大きい背圧 (最大 $\left.10 \mathrm{kgf} / \mathrm{cm}^{2}\right)$ を用いており，拘 束圧が $10 \mathrm{kgf} / \mathrm{cm}^{2}$ を超える場合には，スチール製の三 軸セル，および高圧窒素ガスを使用して実験を行うこと にした。

平均有効主応力一定試験（軸圧増加, 側圧減少: 背圧 $\left.U_{B P}=4.0 \mathrm{kgf} / \mathrm{cm}^{2}\right)$ では, 側圧と軸圧が独立して載荷で

\section{表一1 砂の種類}

\begin{tabular}{l|c|c}
\hline \hline \multicolumn{1}{c|}{ 砂 } & 粒径 $(\mathrm{mm})$ & 比重 \\
\hline 豊浦砂 & $0.11 \sim 0.26$ & 2.65 \\
相馬砂 $\mathrm{A}$ & $0.42 \sim 0.84$ & 2.65 \\
相馬砂 $\mathrm{B}$ & $0.84 \sim 2.00$ & 2.65 \\
\hline
\end{tabular}

表一2 薬液の眍合 $\left(1 \mathrm{kgf} / \mathrm{cm}^{2}=98 \mathrm{kPa}\right)$

\begin{tabular}{|c|c|c|c|c|c|}
\hline \multicolumn{3}{|c|}{ 薬液瀑度 $\mathrm{N}(\boldsymbol{q}(\boldsymbol{)})$} & 15 & 35 & $35 \mathrm{H}$ \\
\hline & \multicolumn{2}{|c|}{ 水ガラス $\mathrm{Na}_{2} \mathrm{O} ・ 3 \mathrm{SiO}_{2}$} & 15 & 35 & 35 \\
\hline 配 & グリオキザール & {$[\mathrm{CHO}]_{2}$} & 5 & 5 & 7.2 \\
\hline \multirow[t]{2}{*}{ 合 } & リン酸 & $\mathrm{H}_{3} \mathrm{PO}_{4}$ & 1.2 & 1.2 & 1.2 \\
\hline & 蒸留水 & $\mathrm{H}_{2} \mathrm{O}$ & 78.8 & 58.8 & 56.6 \\
\hline \multicolumn{3}{|c|}{ ダル強度 $\mathrm{c}_{0}\left(\mathrm{kgf} / \mathrm{cm}^{2}\right)$} & 0.09 & 0.25 & 0.31 \\
\hline
\end{tabular}


きる三軸装置を用いており，軸圧の値は，変形中の断面 積の変化を考えて決定した. 各載荷段階における圧密終 了の判定は, 10 分間に軸方向変位が，1/100 mm 以下と なる条件を基準とした。

固結砂の背圧は, 比較的大きい値を用いているが，こ れは Krizek ら ${ }^{17)}$ の指摘するように背圧が大きくない限 り，高い間隙圧係数 $B$ 值が得られなかったためである. 非排水試験, 平均有効主応力一定試験（両端排水）にお いて， $B$ 值はすべて 0.95 以上となっているので，供試 体はほぼ完全に飽和していると考えることができる.

供試体の形状は，すべての試験において，直径 $5 \mathrm{~cm}$, 高さ $10 \mathrm{~cm}$ である. なお，供試体の上下端における端 面摩擦の影響を除くために，シリコングリースをはさん だ 2 重のドーナツ型ゴム膜を用いており，排水が可能て ある。

\section{4. 固結砂のダイレイタンシーについて}

図一1 には，相馬砂 $\mathrm{A} \quad\left(N=0,15,35,35 \mathrm{H} \%, \gamma_{d}=\right.$ $\left.1.58 \mathrm{~g} / \mathrm{cm}^{3}\right)$ の応力〜ひずみ関係を示す. $N=0 \%$ は未 固結な飽和砂の排水試験である.図一1より, 固結砂の ダイレイタンシーは未固結なものより相当増加している ことがわかる、 $N=15,35 \%$ では，破壊時体積ひずみ $\varepsilon_{V f}$ が，いずれも $4 \%$ 以上となっている. 正の体積ひす み (膨張) は，間陌が増加して給水されたことを意味す るので，破壊時にはゲルの連続性がかなり消失している

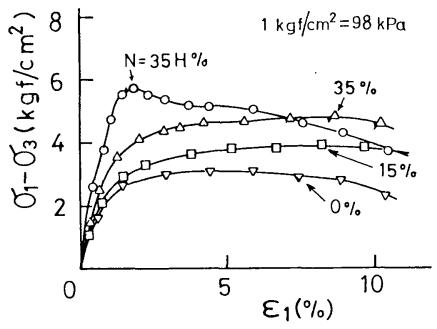

(a) 軸差応力 $\left(\sigma_{1}-\sigma_{3}\right)$ と軸ひずみ $\varepsilon_{1}$ の関係

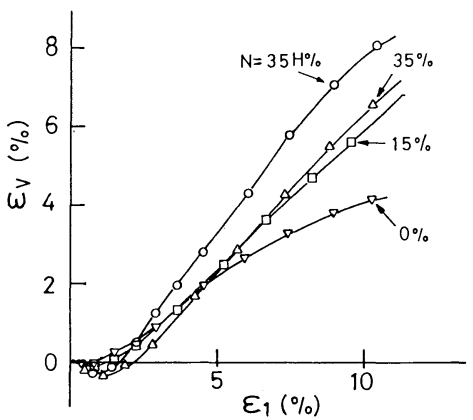

(b) 体積ひずみ $\varepsilon_{V}$ と軸ひずみ $\varepsilon_{1}$ の関係

図一1 相馬砂 A $\left(N=0,15,35,35 \mathrm{H} \%, \gamma_{d}=1.58 \mathrm{gf} / \mathrm{cm}^{3}\right)$ の応力〜ひずみ関係 $\left(\sigma_{3}^{\prime}=1.0 \mathrm{kgf} / \mathrm{cm}^{2}\right)$
と思われる. 一方， $N=35 \mathrm{H} \%$ では， $\varepsilon_{v f} \doteqdot 0 \%$ であり， 破壊強度 $\left(\sigma_{1}-\sigma_{3}\right)_{f}$ はゲル強度に基づく粘着力に大きく 依存していると考えられる. $N=15,35 \%$ において, 破壊強度は未固結なものより大きくなっているが，これ はゲル強度に基づく粘着力の影響だけではない. 固結砂 の破壊時のダイレイタンシー係数 $\left(d \varepsilon_{V} / d \varepsilon_{1}\right)_{f}$ が未固結 砂のものに比べて大きくなっているので，ダイレイタン シーの影響も考慮する必要がある.

ダイレイタンシー係数 $\left(d \varepsilon_{V} / d \varepsilon_{1}\right)$ は, 変形の初期を 除いて, 固結砂の方が未固結砂より大きく,さらに, ゲ ル強度が大きいほど増加している. これは, 砂粒子間隙 のゲルが粒子の周辺で不動域を形成しているので, 見掛 け上，粒径が大きくなり，粒子が隣接する粒子を乗り越 える際に, この不動域も乗り越える必要が生じるためで あろう。また，この現象はダイレイタンシーが増加して いるので見掛け上の密度増加作用 ${ }^{19)}$ として考えることも できる. しかし, この密度増加作用は, 必ずしもゲル強 度だけではなく，ゲルと粒子の付着性状にも影響を受け る. 図一2,3には，ガラスビーズ (粒径 $1.6 \mathrm{~mm}$ ) を水 ガラスおよびアクリルアミドで固めた固結物のダイレ イタンシー特性に及ぼす付着性状の影響を示す。付着性 状は，ガラスビーズの表面をテフロン塗布することによ り変化させた.テフロン塗布することにより,ガラスビー ズの間隙に占めるゲルの体積率が変化することも考えら れるが, 供試体の密度, および供試体に占めるガラスビー ズの重量より求められるゲルの体積率は, 塗布の有無に

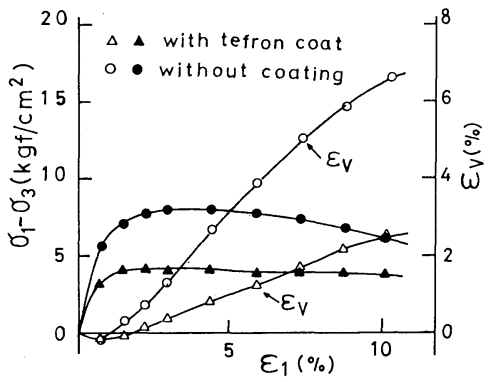

図一2 水ガラス薬液 $(N=35 \%)$ で固めたガラスビーズの応 カ〜ひずみ関係 $\left(\sigma_{3}=3.0 \mathrm{kgf} / \mathrm{cm}^{2}\right)$

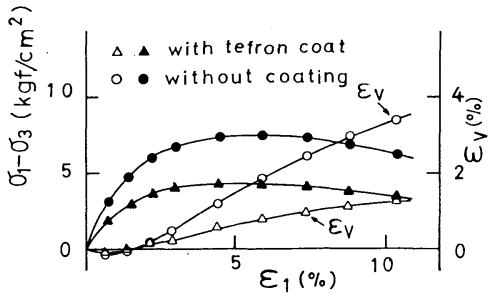

図一3 アクリルアミド（主剤濃度 $20 \%$ ）で固めたガラスビー ズの応力〜ひずみ関係 $\left(\sigma_{3}=3.0 \mathrm{kgf} / \mathrm{cm}^{2}\right)$ 
よらずほぼ等しいので, 図一2,3の結果は,主に付着性 状の相違により生じたものとして考えることができる. これらの結果より，テフロン塗布によって付着力が低下 すると, ダイレイタンシーが減少し, 強度自体も塗布し ていない場合に比して著しく低下することがわかった。

\section{5. 固結砂の排水せん断特性}

\section{（1）固結砂の応力〜ひずみ関係について}

図一4には,相馬砂 A $\left(N=35 \mathrm{H} \%, \gamma_{d}=1.58 \mathrm{~g} / \mathrm{cm}^{3}\right)$ の軸差応力 $\left(\sigma_{1}-\sigma_{3}\right)$, 体積ひずみ $\varepsilon_{V}$, と軸ひずみ $\varepsilon_{1}$ の 関係を示す.

図一4に示したように固結砂のダイレイタンシーはか なり大きいので, 固結砂の強度発現機構を解明するため には, 破壊強度に占めるダイレイタンシー成分の影響を 調べることが重要である.ダイレイタンシー補正式とし ては,いくつか提案されているが,ここでは Rowe $\mathrm{e}^{20)}$ のス トレスーダイレイタンシー式（1）を用いることにした.

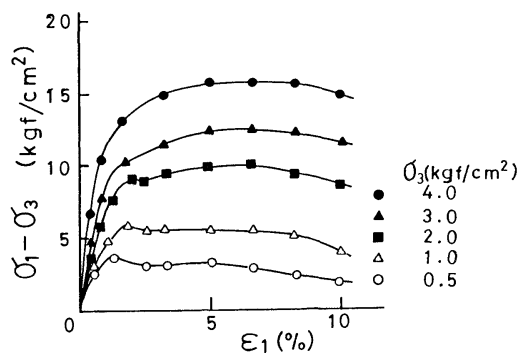

(a) 軸差応力 $\left(\sigma_{1}-\sigma_{3}\right)$ と軸ひずみ $\varepsilon_{1}$ の関係

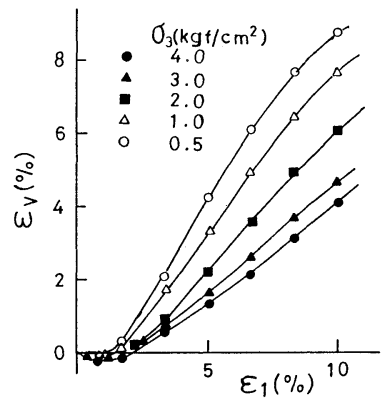

(b) 体積ひずみ $\varepsilon_{v}$ と軸ひずみ $\varepsilon_{1}$ の関係

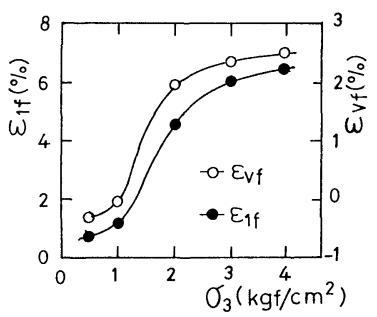

（c）破壊時軸ひずみ $\varepsilon_{1 s}$ と破壊時体積ひずみ $\varepsilon_{v s}$

図一4 相馬固結砂 A $\left(N=35 \mathrm{H} \%, \gamma_{d}=1.58 \mathrm{gf} / \mathrm{cm}^{3}\right)$ の忍力〜 ひずみ関係 $\left(1 \mathrm{kgf} / \mathrm{cm}=98 \mathrm{kPa}, 1 \mathrm{gf} / \mathrm{cm}^{3}=9.8 \mathrm{kN} / \mathrm{m}^{3}\right)$
$\left(\sigma_{1}-\sigma_{3}\right)_{R}=\sigma_{1} /\left(1+d \varepsilon_{V} / d \varepsilon_{1}\right)-\sigma_{3}$

$\left(\sigma_{1}-\sigma_{3}\right)_{R}$ : 摩擦のみに起因する強度成分

図一5（a)，(b) には，図一4で示した試料の破壊時 のモール円，および，式（1）で補正した破壊時のモー ル円を示す。

図一6には，軸ひずみ $\varepsilon_{1}=10 \%$ の段階で式（1）補 正を行った破壊包絡線を示している. $\varepsilon_{1}=10 \%$ の段階 ではダイレイタンシー係数がゼロとなっていないので, これ以上変形を進めるべきであるが, 供試体が偏心する ためこの時点まで変形を与えることにした.

図一5 (a) の場合, モールの包絡線は直線近似が可能と なる.一方, 図一5 (b) では包絡線を 1 本の直線で表わ すことができず P点で折れ曲がっている．側圧が大きい 範囲では, 包絡線は原点を通る直線として表わすことが でき,この傾き $\phi_{R f}\left(=30.5^{\circ}\right)$ は, 未固結砂の $\phi_{R f}\left(=29.5^{\circ}\right)$ よりわずかに大きくなっているが，ほぼ一致していると 考えられる. 側圧が小さい範囲では, 包絡線は $\mathrm{P}$ 点で折 れ曲がっている.このように包絡線が折れ曲がる理由は, 式（1）の補正には粘着力を含んでおらず, 側圧が小さ い範囲では, 破壊時に粘着力成分が発揮されているため

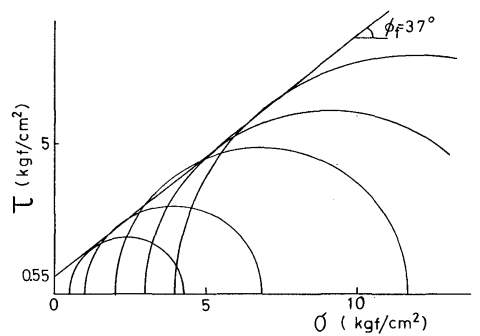

(a) 破壊時の軸差応力 $\left(\sigma_{1}-\sigma_{3}\right)_{5}$ と側圧 $\sigma_{3}$ の関係

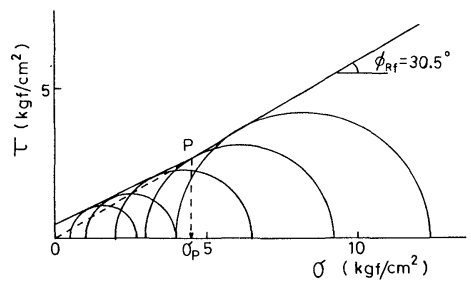

(b) 式（1）で補正した破壊時の軸差応力 $\left(\sigma_{1}-\sigma_{3}\right)_{R S}$ と側圧 $\sigma_{3}$ の関係

図一5 相馬砂 A $\left(N=35 \mathrm{H} \%, \gamma_{d}=1.5 \mathrm{gf} / \mathrm{cm}^{3}\right)$ におけるモー ルの包絡線

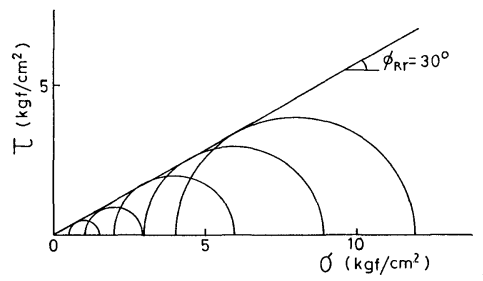

図一 $6 \varepsilon_{1}=10 \%$ における式 $(1)$ 補正のモール円 
であろう．側圧が小さい範囲においても，破壊時の粘着 力の大きさは，側圧が増加するにつれて低下すると考え られる.このため, 側圧が小さい範囲の傾き（図—5(b)) は， $\phi_{R f}$ より小さくなっているのであろう.

図一4の応力〜ひずみ関係においては，側圧が小さい 範囲では軸ひずみが小さい段階でピーク点が発生してい るが，側圧が大きくなるにつれて明瞭なピーク点はみら れなくなる. Stezler ${ }^{5)}$ も固結砂の応力〜ひずみ関係が 図一4 と同様である結果を得ている．このような応力〜 ひずみ関係の拘束圧依存性は, 岩石力学の分野において “Brittle-Ductile-Transition”21) として知られている.

破壊強度に及ぼす粘着力の影響がほとんど消失する側 圧を遷移圧 $\sigma_{t r}$ とすると, $\sigma_{t r}$ の大きさは, 図一5 (b)に 示したP点における垂直応力 $\sigma_{P}$ を用いて式 $(2)$ で表 わすことができる.

$$
\sigma_{t r}=2 \cdot \sigma_{P} /\left(\cos ^{2} \phi_{R f}\right) /\left[1+\tan ^{2}\left(45+\phi_{R f} / 2\right)\right] \cdots
$$

$\varepsilon_{1}=10 \%$ において, 式 (1) で補正したモール円の包 絡線は, 図一6に示したように側圧の大きさに関係なく, 原点を通る直線で表わすことができ, その傾き $\phi_{R r}(=$ $\left.30^{\circ}\right)$ は未固結砂の $\phi_{R r}\left(=29.5^{\circ}\right)$ とほぼ等しい. したがっ て, $\varepsilon_{1}=10 \%$ においては, 粘着力がほとんど完全に消 失していることになる.

同様な整理を他の固結砂に対して行った結果を表一3 に示しているが, これらの場合もダイレイタンシー補 正により求めた有効応力表示の粘着力と摩擦角は, 破壊 時, $\varepsilon_{1}=10 \%$ 時において未固結砂とほぼ一致している. 破壊強度に及ぼす粘着力の影響がほとんど消失する遷移 圧を式（2）を用いることにより求めてみると, その大 きさは, 砂の粒径が小さくゲル強度が増加するにつれて 大きくなっていることがわかる.

\section{（2）ゲル粘着力の破壊について}

土のせん断強度の構成成分に関する研究は, 数多くな されており ${ }^{22), 23}$ 主に1) 摩擦成分, 2) ダイレイタンシー 成分，3）粘着力成分の三成分が考慮されている. 水ガ ラス系固結砂に比較して, きわめて粘着力が大きい軟

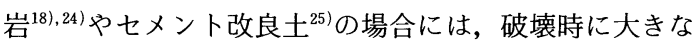
体積膨張が生じていることはないので, 粘着力の影響の みが支配的になると考えられるが, 固結砂の場合には,

\section{表一3 モールの包絡線による固結砂の粘着力 $c$ と摩擦角 $\phi$}

\begin{tabular}{|c|c|c|c|c|c|c|c|c|}
\hline 砂 & $N(\%)$ & $\mathrm{c}_{f}$ & $\phi_{f}$ & $C_{R f}$ & $\phi_{\mathrm{Rf}}$ & $\mathrm{C}_{\mathrm{Rr}}$ & $\phi_{\mathrm{Rr}}$ & $\sigma_{\mathrm{tr}}$ \\
\hline 豊浦砂 & 0 & 0 & 37.5 & 0 & 29 & 0 & 29 & - \\
\hline 豐浦砂 & 35 & 0.45 & 39.5 & 0 & 30 & 0 & 29 & 1.94 \\
\hline 相馬砂A & 0 & 0 & 37 & 0 & 29.5 & 0 & 29.5 & - \\
\hline 相馬砂 A & 15 & 0.10 & 39 & 0 & 29.5 & 0 & 29.5 & $<0.20$ \\
\hline 相馬砂A & 35 & 0.25 & 39 & 0 & 30.5 & 0 & 29.5 & 1.21 \\
\hline 相馬酹 A & $35 \mathrm{H}$ & 0.55 & 37.5 & 0 & 30.5 & 0 & 30 & 3.00 \\
\hline 相馬砂 B & 0 & 0 & 37 & 0 & 29.5 & 0 & 29.5 & - \\
\hline 相馬砂 B & 35 & 0.20 & 39.5 & 0 & 30 & 0 & 29.5 & 0.94 \\
\hline
\end{tabular}

ゲル自身の強度が小さいため，ダイレイタンシーの影響 も考慮する必要性が生じる. 粘着力の大きさは, 等せん 断ひずみ線を用いて決定される場合もあるが，ここでは 粘着力を含めた Rowe $\mathrm{e}^{20)}$ のストレスーダイレイタンシー 式（３）により求めた。 $\phi$ 值は, 未固結砂の場合, 式 ( 3 ) で $c=0$ として, 各変形段階で求めてみるとほぼ一定值 $\left(=\phi_{R r}\right)$ となったので, 固結砂の $\phi$ も表一3の $\phi_{R r}$ の値 を用い, 変形過程で一定と考えた.

$$
\begin{aligned}
& \sigma_{1} /\left(1+d \varepsilon_{v} / d \varepsilon_{1}\right)=\sigma_{3} \tan ^{2}(45+\phi / 2) \\
& \quad+2 c \tan (45+\phi / 2) \cdots \cdots \cdots \cdots \cdots \cdots \cdots
\end{aligned}
$$

固結砂の粘着力は, 間隙ゲルにより発揮されることに なるので, ゲルの破壊について考える必要がある．この ゲルの破壊は, 砂骨格に作用している応力状態よりもむ しろ変形量（せん断ひずみ，体積ひずみ）が重要になる と思われるので, 粘着力と変形量の関係を調べることに した。

図一7には，式（3）を用いて得られる粘着力 $c$ とせ ん断ひずみ $\left(\gamma=\varepsilon_{1}+\varepsilon_{V} / 3: \varepsilon_{V}\right.$ は膨張を正とする) の関 係を示す。ただし, 変形のごく初期においては, 摩擦角 が十分に発揮されないと思われるので， $c$ は $\gamma$ が $1 \%$ 程度以上の場合について求めることにした. 粘着力 $c$

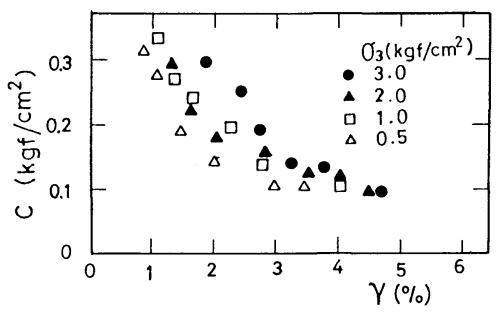

（a ）豊浦砂 $\left(N=35 \%, \gamma_{d}=1.56 \mathrm{gf} / \mathrm{cm}^{3}\right)$

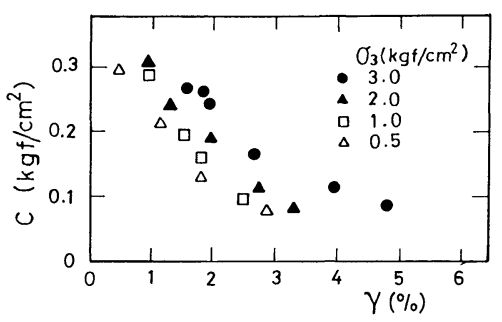

(b) 相馬砂 A $\left(N=35 \%, \gamma_{d}=1.58 \mathrm{gf} / \mathrm{cm}^{3}\right)$

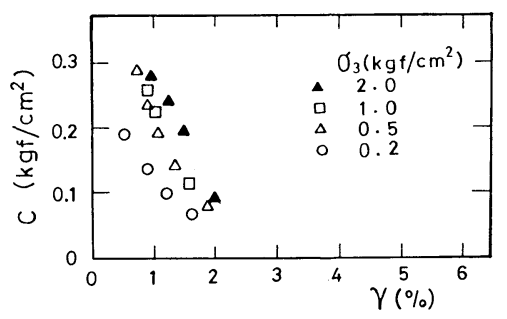

(c) 相馬砂 B $\left(N=35 \%, \gamma_{d}=1.59 \mathrm{gf} / \mathrm{cm}^{3}\right)$

図一7 固結砂のせん断ひずみ $\gamma$ と粘着力 $c$ の関係 


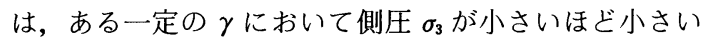
ので, 粘着力 $c$ は $\gamma$ のみの関数とならず, 側圧の影響 を受けていることがわかる.これは， $\gamma$ が等しくても側 圧が小さいほど体積ひずみ $\varepsilon_{V}$ が大きくなるため, その 分だけゲルの連続性が失われて粘着力が小さくなってい るのであろう.

体積ひずみ $\varepsilon_{V}$ と粘着力の関係を考える場合, この $\varepsilon_{V}$ は, 平均主応力の変化による $\varepsilon_{V P}$ と, せん断応力のみの 変化による $\varepsilon_{v d}$ の和より成り立つとして考えることがで き,これを式 $(4)$ に示す. ただし， $\varepsilon_{v}, \varepsilon_{V P}, \varepsilon_{V a}$ はす べて膨張側を正としている.

$$
\begin{gathered}
\varepsilon_{v}=\varepsilon_{v P}+\varepsilon_{V d}=-c_{c} /\left(1+e_{0}\right) \log \left(\sigma_{m}^{\prime} / \sigma_{c}^{\prime}\right)+\varepsilon_{v d} \cdots \cdots(4) \\
c_{c} \text { : 圧縮指数 } \quad e_{0}: \text { 初期間隙比 } \\
\sigma_{m}^{\prime}: \text { 平均主応力 } \quad \sigma_{c}^{\prime} \text { : 圧密応力 }
\end{gathered}
$$

図一8には豊浦固結砂 $\left(N=35 \%, \gamma_{d}=1.56 \mathrm{gf} / \mathrm{cm}^{3}\right)$ の等方圧密試験結果を示しており, $\varepsilon_{V P} \sim \log \sigma_{m}^{\prime}$ 関係は 未固結砂とほぼ一致している. また, 圧密除荷後の固結 砂の一軸強度 $q_{U}$ は, 圧密試験前の $q_{U}$ と差異がないため $\varepsilon_{V P}$ が粘着力に及ぼす影響はほとんどないと考えること

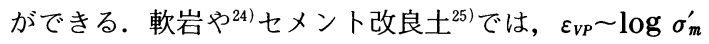
関係に降伏が生じて粘着力が等方圧の影響を受けると指 摘している例もあるが, 本研究で取り扱っている水ガラ ス系の固結砂では砂粒子が骨格を形成しているため,こ の程度の等方圧のもとでは， $\varepsilon_{V P}$ は粘着力の破壊と無関 係であると考えられる. したがって, 粘着力の破壊を体

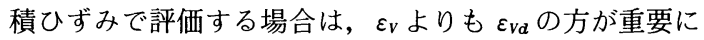
なろう。

式( 4$)$ より $\varepsilon_{v d}$ を求めて, $c \sim \varepsilon_{v d}$ の関係を図一 9 に示 す.なお, 式 $(4)$ の $c_{c}$ の值は固結砂の等方圧密試験に より求めた. $c \sim \varepsilon_{V d}$ の関係は側圧の大きさに左右され ず一義的な関係にあることがわかる． $\varepsilon_{v d}$ の増加に対す る $c$ の低下率は, 粒径が大きいほど増加している. また, $c$ の最大值は, 粒径を問わず, $0.30 \mathrm{kgf} / \mathrm{cm}^{2}$ 程度となり, ゲル強度 $c_{0}\left(0.25 \mathrm{kgf} / \mathrm{cm}^{2}\right)$ とかなり一致していると考 えられる.

以上の結果より，粘着力の破壊を変形量で評価する場

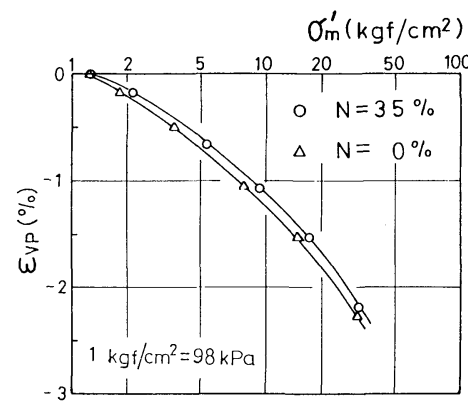

豊浦砂 $\left(N=35 \%, \gamma_{d}=1.56 \mathrm{gf} / \mathrm{cm}^{3}\right)$ の等方圧密試験

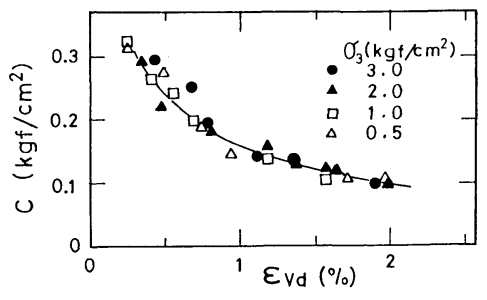

(a ) 豊浦砂 $\left(N=35 \%, \gamma_{d}=1.56 \mathrm{gf} / \mathrm{cm}^{3}\right)$

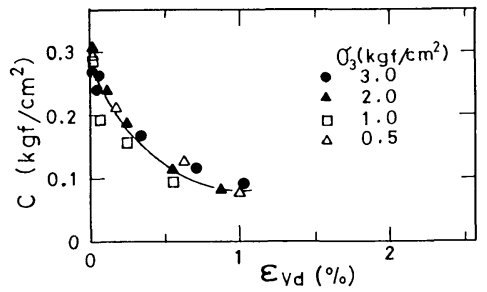

(b ) 相馬砂 A $\left(N=35 \%, \gamma_{d}=1.58 \mathrm{gf} / \mathrm{cm}^{3}\right)$

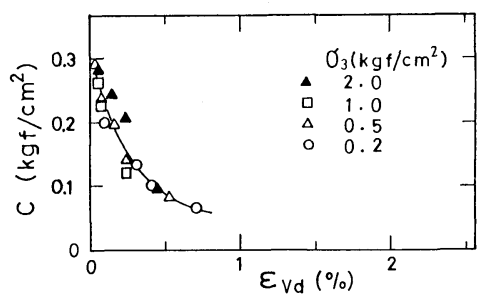

(c ) 相馬砂 B $\left(N=35 \%, \quad \gamma_{d}=1.59 \mathrm{gf} / \mathrm{cm}^{3}\right)$

\section{図一9 固結砂の体積ひずみ $\varepsilon_{v d}$ と粘着力 $\boldsymbol{c}$ の関係}

合， $c$ とせん断ひずみ $\gamma$ の関係には一義的な関係がみ られず拘束圧の影響を受けるが， $c$ とせん断応力のみの 変化による $\varepsilon_{V d}$ の間には一義的な関係が成立することが わかった. また, 粘着力 $c$ の大きさは, 最大限に発揮 されてもゲル強度 $c_{0}$ 程度であることが明らかとなった。

\section{6. 固結砂の非排水せん断特性}

前節では，排水試験における粘着力と変形量の関係に ついて論じたが，ここでは，非排水試験における粘着力 の破壊について考えることにする。

図一10には豊浦砂 $\left(N=0,35 \%: \gamma_{d}=1.56 \mathrm{gf} / \mathrm{cm}^{3}\right)$ の非排水試験における応力経路を示す.非排水試験では, $\gamma=15 \%$ までせん断しているが, 試験後にセルより供 試体を取り出してみても，すべり面は発生しておらず， ゲルの破壊は認められない。表一4には固結砂の一軸強 度 $q_{v}$ と, 非排水試験 $\left(\sigma_{c}^{\prime}=10 \mathrm{kgf} / \mathrm{cm}^{2}\right)$ において $\gamma=$ $15 \%$ のひずみを与えた後セルより取り出した供試体の 一軸強度 $q_{u}^{\prime}$ を示しているが，固結砂の粘着力は $\gamma=15$ \%においても完全に消失していないことになる．表一4 の結果は， $\gamma=15 \%$ のせん断ひずみによる粘着力の破 壊の程度を示したものであり, 粒径の小さい豊浦砂が 相馬砂 $\mathrm{A}$, 相馬砂 $\mathrm{B}$ に比較して粘着力の破壊が少ないと 


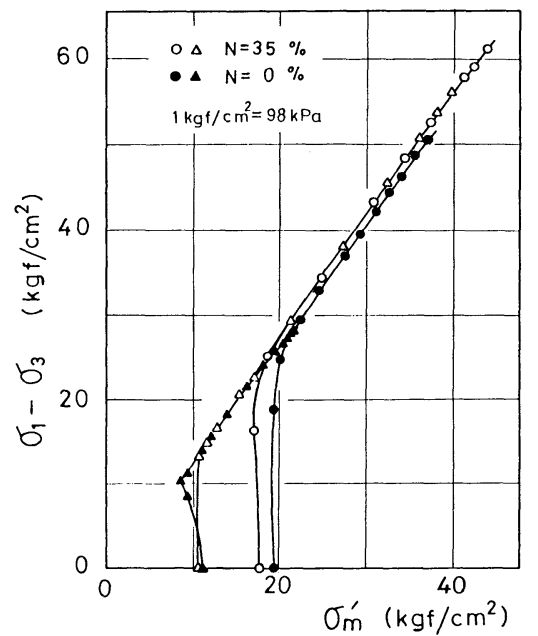

図一10 豊浦砂 $\left(N=0,35 \%, \gamma=1.56 \mathrm{gf} / \mathrm{cm}^{3}\right)$ の非排水試 験（高圧下）における応力経路

表一4 固結砂の一軸強度 $\left(1 \mathrm{kgf} / \mathrm{cm}^{2}=98 \mathrm{kPa}\right)$

\begin{tabular}{l|c|c|c}
\hline \hline \multicolumn{1}{c|}{ 砂 } & $\begin{array}{c}\text { 䒱液 } \\
\mathrm{N}(\%)\end{array}$ & $\begin{array}{c}\mathrm{qu} \\
\left(\mathrm{kgf} / \mathrm{cm}^{2}\right)\end{array}$ & $\begin{array}{c}\mathrm{q} \mathrm{u} \\
\left(\mathrm{kgf} / \mathrm{cm}^{2}\right)\end{array}$ \\
\hline 豐浦砂 & 35 & 4.13 & 2.15 \\
相馬砂 $\mathrm{A}$ & 35 & 2.86 & 1.15 \\
相馬砂 $\mathrm{B}$ & 35 & 2.32 & 0.13 \\
\hline
\end{tabular}

考えることができる.排水試験では, $\varepsilon_{1}=10 \%(\gamma \doteqdot 11 \%)$ において，すべり面が発生し，間隙ゲルによる結合が完 全に消失している結果を考慮すると, 粘着力 $c$ と $\gamma$ の 関係は排水試験と非排水試験とで全く異なることにな り, 固結砂の強度発現機構は, 排水条件によって影響さ れると思われる.

前川らは ${ }^{26)}$, 理藻質軟岩の排水・非排水試験を行った 結果，その強度特性が排水条件により全く異なり，七メ ンテーション成分（粘着力）の影響と側圧条件を考慮し た解析が必要であることを指摘している．珠藻軟岩にお いても, 水ガラス系固結砂の場合と同様に, 粘着力とせ ん断ひずみの関係が排水条件により異なることが，その 強度特性を複雑にしている原因の 1 つではないかと推定 される.

前節において，粘着力は，せん断ひずみ $\gamma$ よりも， むしろせん断応力のみの変化による体積ひずみ $\varepsilon_{V d}$ 之密 接な関係にあることを述べた，非排水試験では，体積ひ ずみ $\varepsilon_{V}$ がゼロとなるが，平均主応力が変化するため見 掛け上， $\varepsilon_{V d}$ が発生し，その大きさは式 $(5)$ で表わす ことができる.

$$
\varepsilon_{V d}=c_{c} /\left(1+e_{0}\right) \cdot \log \left(\sigma_{m}^{\prime} / \sigma_{c}^{\prime}\right)
$$

図一11には，3種類の固結砂 $\left(N=35 \%, \sigma_{c}^{\prime}=10\right.$ $\left.\mathrm{kgf} / \mathrm{cm}^{2}\right)$ の式 (5) による体積ひずみ $\varepsilon_{V d}$ とせん断ひ
ずみ $\gamma$ の関係を示しており， $\varepsilon_{V d}$ の大きさは粒径にあま り関係なく $\gamma=15 \%$ においても $\varepsilon_{V d}=1.0 \%$ 程度となっ ている.

前節の図一6には排水試験における $c \sim \varepsilon_{v d}$ の関係を 示した．豊浦砂の場合には $\varepsilon_{V d}=1.0 \%$ において粘着力 がまだ消失していないが，一方粒径が大きい相馬砂 Bで は, $\varepsilon_{V d}=1.0 \%$ において粘着力はほとんぞ消失してい る.したがって，排水試験における $c$ と $\varepsilon_{v d}$ の関係は， 上述した表一4の結果を説明することも可能となろう. 以上の結果より，粘着力の破壊をせん断ひずみで評価す ることは, 排水試験と非排水試験とでかなり異なるが, $\varepsilon_{V d}$ で評価した場合は，試験方法や拘束圧の大きさを問 わず統一して考えることができ， $c$ と $\varepsilon_{V d}$ の間に一義的 な関係が成立していると推定できる.

図一10の応力経路より固結砂の粘着力を求めること は圧密圧が大きいため困難である. 図一12 には圧密圧 が小さい範囲で行った非排水試験（豊浦砂, $N=35 \%$, $\left.\gamma_{d}=1.59 \mathrm{gf} / \mathrm{cm}^{3}: \sigma_{c}^{\prime}=0.2,0.5 \mathrm{kgf} / \mathrm{cm}^{2}\right)$ の結果を示し ており,この応力経路より, せん断初期で発揮されてい る粘着力を求めることにした。応力経路より得られる切 片を $\alpha$, 傾きを $\beta$ とすると, モ一ルの包絡線表示の粘着 力 $c$ は式 (6) で与えられる.

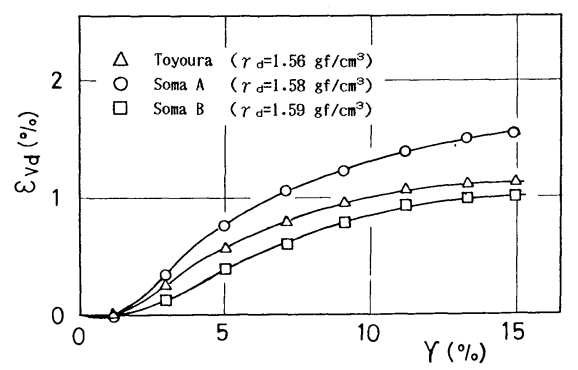

図一11 固結砂 $\left(N=35 \%, \sigma_{c}^{\prime}=10 \mathrm{kgf} / \mathrm{cm}^{2}\right)$ のせん断ひずみ $\gamma$ と体積ひずみ $\varepsilon_{v d}\left(1 \mathrm{kgf} / \mathrm{cm}^{2}=98 \mathrm{kPa}\right)$

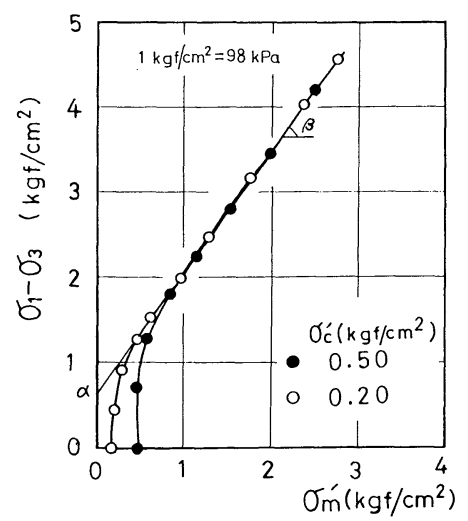

図一12 豊浦砂 $\left(N=35 \%, \gamma_{d}=1.56 \mathrm{gf} / \mathrm{cm}^{3}\right)$ の非排水試験（低 圧下）における応力経路 
表一5 応力経路より求められる固結砂の粘着力

\begin{tabular}{l|c|c|c}
\hline \hline \multicolumn{1}{c|}{ 砂 } & $\begin{array}{c}r_{\mathrm{d}} \\
\left(\mathrm{gf} / \mathrm{cm}^{3}\right)\end{array}$ & $\begin{array}{c}\text { 薬液 } \\
\mathrm{N}(\%)\end{array}$ & $\begin{array}{c}\text { 粘着力 } \mathrm{c} \\
\left(\mathrm{kgf} / \mathrm{cm}^{2}\right)\end{array}$ \\
\hline 豊浦砂 & 1.58 & 15 & 0.08 \\
䅱浦砂 & 1.56 & 35 & 0.29 \\
相馬砂A & 1.60 & 15 & 0.05 \\
相馬砂 $\mathrm{A}$ & 1.59 & 35 & 0.28 \\
相馬砂 $\mathrm{A}$ & 1.59 & $35 \mathrm{H}$ & 0.31 \\
相馬砂 $\mathrm{B}$ & 1.60 & 35 & 0.25 \\
\hline \multicolumn{3}{|c}{$1 \mathrm{gf} / \mathrm{cm}^{3}=9.8 \mathrm{kN} / \mathrm{m}^{3}, \quad 1 \mathrm{kgf} / \mathrm{cm}^{2}=98 \mathrm{kPa}$}
\end{tabular}

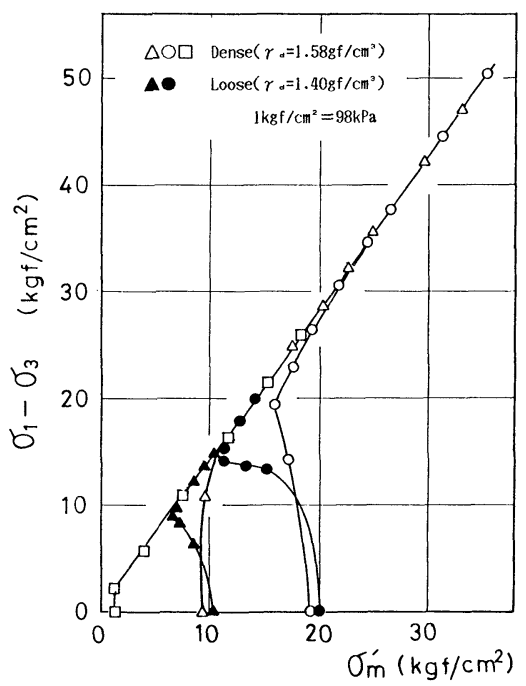

図一13 固結砂（相馬砂 A， N=35％) の忍力経路に及ぼす密 度の影霜

$$
c=1.5 \cdot \alpha \cdot[(3+2 \tan \beta) \cdot(3-\tan \beta)]^{-1 / 2}
$$

表一5には式 $(6)$ により求めた粘着力 $c$ の值を示して いるが,これらの值は,ほぼゲル強度（表一2）に等し くなっている，排水試験において，せん断過程で発揮さ れる最大の粘着力はゲル強度程度となっており, 非排水 試験の結果とも一致している.

図一13には, 固結砂の応力経路に及ぼす密度の影響 を示している.密詰め, ゆる詰めともに応力経路は最終的 に完全に一致していることがわかる. 固結砂の強度は密 度にかなり影響されることが指摘されているが27), 図一 13 の結果により，固結砂の強度に及ぼす密度の影響は ダイレイタンシーのある場合に生じるものであり, 粘着 力の大きさとしては密度に無関係であると推察できる.

\section{7. 平均有効主応力一定試験における固結砂の せん断特性}

固結砂の粘着力成分 $c$ は, せん断応力の変化のみに よる体積変化 $\varepsilon_{v d}$ と密接な関係にあることを述べてきた が平均有効主応力一定試験を行い, 直接 $\varepsilon_{V d}$ を求めるこ とにした.
図一14には,豊浦砂 $\left(N=35 \mathrm{H}, 35,0 \%, \gamma_{d}=1.56\right.$ $\left.\mathrm{gf} / \mathrm{cm}^{3}, \sigma_{m}^{\prime}=1.0 \mathrm{kgf} / \mathrm{cm}^{2}\right)$ の試験結果を示す. 図一14 (a) より固結砂のダイレイタンシーは未固結砂に比してその 発生が遅らされており, この傾向はゲル強度が大きいも のほど著しい.したがって,固結砂の粘着力はダイレイタ ンシーの発生を遅らせている間に発揮されると考えるこ とができる．図一14 (b) で示した軸差応力と軸ひずみ の関係において, せん断初期の軸差応力は固結砂の方が 末固結砂に比べて大きいが，これはダイレイタンシーが 生じる以前に発揮されたものである。図一14(c) には 軸ひずみと体積ひずみ $\varepsilon_{V d}$ の関係を示している．図一14 (a) の軸差応力と体積ひずみの関係では, 粘着力がダイ レイタンシーを遅らせると述べたが, 図一14 (c) で示した軸ひずみと体積ひずみの関係においては, 固結 砂のダイレイタンシーが未固結砂よりも大きくなってい る.これらの結果により, 固結による砂の強化作用とし ては, 変形のごく初期においてダイレイタンシーに抵抗

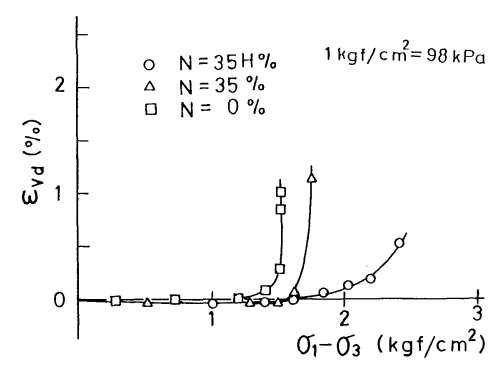

(a) 体積ひずみ $\varepsilon_{V d}$ と軸差応力 $\left(\sigma_{1}-\sigma_{3}\right)$ の関係

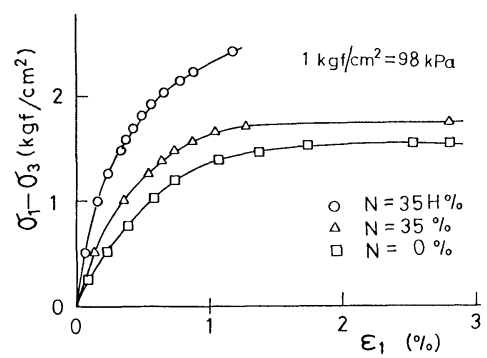

(b) 軸差応力 $\left(\sigma_{1}-\sigma_{3}\right)$ と軸ひずみ $\varepsilon_{1}$ の関係

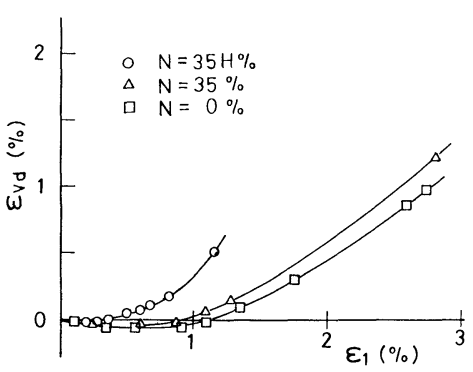

（c）軸ひずみ $\varepsilon_{1}$ と体積ひずみ $\varepsilon_{V}$ の関係

図一14 豊浦砂 $\left(N=0,15,35,35 \mathrm{H} \%, \gamma_{d}=1.56 \mathrm{gf} / \mathrm{cm}^{3}\right)$ の 平均有効主応力一定試験結果 $\left(\sigma_{m}^{\prime}=1.0 \mathrm{kgf} / \mathrm{cm}^{2}\right)$ 
している間に発揮される粘着力成分だけではなく，変形 がある程度進んでいる段階で発揮されるダイレイタン シ一成分も存在していることがわかる. そして，この 2 つの成分は，同時に最大限発揮されるわけではなく，ダ イレイタンシーの発生は粘着力の破壊として考えなけれ ばならない.

図一15には相馬砂 B $\left(N=0,35 \%, \gamma_{d}=1.58 \mathrm{gf} / \mathrm{cm}^{3}\right.$, $\left.\sigma_{m}^{\prime}=1,2,4 \mathrm{kgf} / \mathrm{cm}^{2}\right)$ の結果を示す.図一15においても, 固結砂のダイレイタンシーが粘着力によって遅らされて いるが，変形が進むと固結砂のダイレイタンシーが末固 結砂よりも大きくなっていることがわかる.

また,図一15 (c) に示したせん断ひずみ $\gamma$ と体積ひず み $\varepsilon_{V d}$ の関係において, 固結砂の $\gamma \sim \varepsilon_{V d}$ の関係は一義 的なものとならず，一定の $\gamma$ において平均主応力 $\sigma_{m}^{\prime}$ が 大きいほ亡゙ $\varepsilon_{v d}$ は小さくなっている．前節の図一7，9に おいて, 固結砂の粘着力 $c$ と $\gamma$ の関係は一義的なもの にならず拘束圧の影響を受け， $c$ と $\varepsilon_{V d}$ の間に一義的な

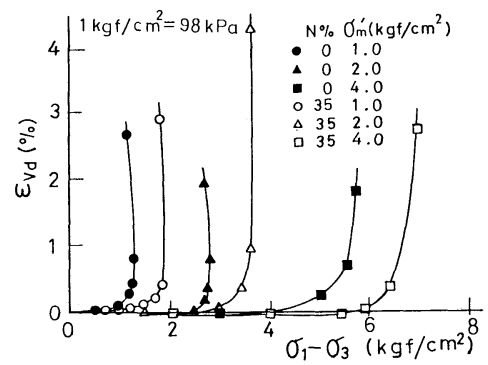

(a) 体積ひずみ $\varepsilon_{V d}$ と軸差応力 $\left(\sigma_{1}-\sigma_{3}\right)$ の関係

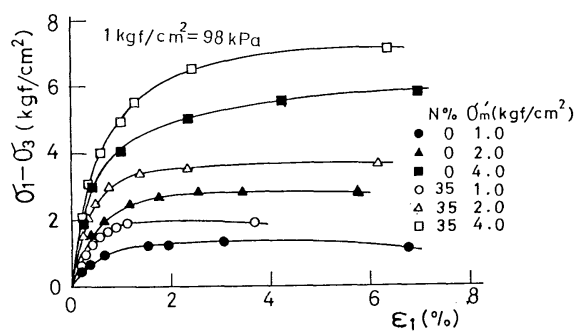

(b) 軸差応力 $\left(\sigma_{1}-\sigma_{3}\right)$ と軸ひずみ $\varepsilon_{1}$ の関係

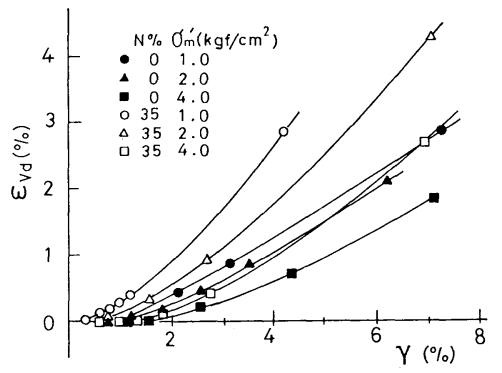

(c) 軸ひずみ $\varepsilon_{1}$ と体積ひずみ $\varepsilon_{v}$ の関係

図一15 固結砂 (相馬砂 $\mathrm{B}, N=35 \%, \gamma_{d}=1.59 \mathrm{gf} / \mathrm{cm}^{3}$ ) の平 均有効主応力一定試験
関係が成立していることを指摘した。これは，固結砂の せん断ひずみ $\gamma$ と体積ひずみ $\varepsilon_{V d}$ の関係が拘束圧に影響 されることを意味しており，図一15 (c) において示し た実験結果と一致していることが明らかとなった.

\section{8. まと め}

本研究は, 弱い結合材（水ガラス系薬液）で固結させ た砂の強度特性に及ぼす粘着力とダイレイタンシーの影 響を，負圧が発生しない有効応力下の条件で調べたもの であり，主な結果は次のとおりである.

（1）三軸排水試験における固結砂のダイレイタン シ一は見掛け上の密度増加作用によって, 未固結砂に比 して増大する.したがって，固結による強度増加作用と しては，ゲル自身の強度に基づく粘着力とダイレイタン

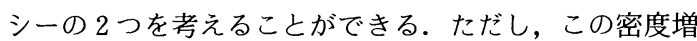
加作用は，ゲルと砂粒子との付着性状に大きく左右され て，付着力が小さい場合には強度増加作用が著しく低下 する.

（2）三軸排水試験により得られる固結砂の応力〜ひ ずみ関係において, 拘束圧が小さい場合には変形初期に おいてピーク点が生じているが，拘束圧が大きくなるに つれて明瞭なピーク点がみられなくなる，そして，破壊 強度に及ぼす強度増加作用としては，拘束圧が小さい場 合には，ゲル強度に基づく粘着力の影響が大きいが，拘 束圧が増すにつれて粘着力の影響は低下し，ダイレイタ ンシーの影響が支配的なものになることが明らかとなっ た.

（３）ゲル粘着力の破壊を変形量で評価する場合, 粘 着力 $c$ とせん断ひずみ $\gamma$ の関係は, 一義的なものとな らず，拘束圧の影響を受けて，排水試験と非排水試験の 結果を統一して説明することができない，せん断応力の みの変化による体積ひずみ $\varepsilon_{V d}$ と粘着力の関係は，拘束 圧や排水条件に影響されず，一義的なものであると思わ れる.また，せん断過程で発揮される粘着力の最大值は, 粒径にあまり左右されず，ホモゲル強度 $c_{0}$ 程度である ことがわかった。

（4）固結砂の強度は, 密度の影響を受けることが指 摘されているが, 非排水試験の応力経路は密度が異なっ ても最終的には完全に一致している，したがって，密度 の差が強度に及ぼす影響は，ダイレイタンシーのある場 合に生じるものであり, 粘着力成分としては, 密度にほ とんど無関係といえる.

（5）平均有効主応力一定試験の結果より，固結砂の ダイレイタンシーの発生は, 未固結なものに比して遅ら されており，この間にゲル強度に基づく粘着力が発揮さ れているが, 変形がある程度進み粘着力が消失している 段階では，固結砂のダイレイタンシーが未固結砂より大 
きくなり, 強度増加に貢献することがわかった．

\section{参 考 文 献}

1) Matuoka, H. : Stress-strain relationships of sands based on the mobilized plane, Soils \& Foundation, Vol.14, No. 2, pp. 77 87, 1974.

2) Nishi, K. and Esashi, Y. : Stress-strain relationships of sand based on elasto-plasticity theory，土木学会論文 報告集, No. 280, pp. 111 122, 1978.

3）森麟・田村昌仁：水ガラス系固結砂の強度に関する 工学的特性, 土木学会論文集, No. 370, 1986.

4) Perez, J., Davidson, R. and Lacroix, Y. : Chemical grouting test programme for Mississippi River locks and dam 26, Geotechnique 32, No.3, pp.217 233, 1982.

5) Stetzler, B. V. : Time-dependent behaviour of chemically Grout-Strengthened Soils, 8th ECSMFE IMPROVEMENT OF GROUND Vol.1, pp.415 420, 1983.

6）三木五三郎：ケミカルグラウトの浸透性に関する新しい 問題点, 第 3 回土質工学研究発表会, pp. 159 162, 1968.

7）加賀宗彦・米倉亮三：水ガラス系薬液を用いた砂質土供 試体の変形・強度特性, 第 15 回土質工学研究発表会, pp. 1653 1656, 1980.

8）坪井直道・池上政雄・野村幸一：薬液注入土のせん断特 性に関する一実験, 鹿島建設技術研究所報告, No. 17, pp. 189 200, 1968.

9）森 鱗・武田安敏：薬液注入による砂の強度劣化につい て, 第 27 回土木学会年次講演会第 3 部, p. 511, 1972.

10）森 麟・佐藤勝久: 結合剤による土の強度增加機構, 土 と基礎, Vol.16, No.12, 1968.

11）春山元寿・山内豊聡：乱したシラスの排水せん断特性に ついて, 土と基礎, Vol.14, No. 8, pp. 27〜33, 1966.

12）春山元寿：えびの吉松地域に分布するシラスのせん断特 性について, 土と基礎, Vol.22, No. 2, pp. 41 47, 1972.

13）西田一彦・香田 満：マサ土の土粒子特性とせん断特性 について, 第 25 回土木学会年次学術講演集第 3 部, pp. 375 376, 1970.

14) Farris, R. J. : Dilatation of granular filled elastomer under high rates of strain, Journal of Applied Polymer Science Vol. 8, pp. 25 35, 1964.
15) Mordecai, M. and Morris, L. H. : An investigation into the changes of permeability occuring in a sandstone when failled triaxial stress condition, 12th Symposium on Rock Mechanics, pp. 221 239, 1970.

16) Mori, A. and Tamura, M. : Effect of dilatancy on permeability in sands stabilized by chemical grout, Soils \& Foundations, Vol.26, No.1, 1986.

17) Krizek, R. J., Benltayf, M. A. and Atmatzidis, D. A. : Effective stress-strain-strength behaviour of silicategrouted sand, Proc. of Conf. on Grout in Geotechnical Engineering, pp. 482 497, 1982.

18）足立紀尚 - 小川豊和：堆積軟岩の力学的特性と破壊規準, 土木学会論文報告集, No. 295, pp. 51 63, 1980.

19) Ziegel, K.D. and Romanov, A. : Modulus reinforcement in elastomer composite, 1 inorganic filler, Journal of Applied Polymer Science, Vol.17, pp.1119 1131, 1973.

20) Rowe, P.W. : The stress-dilatancy relation for static equilibrium of an assembly of particle in contact, Proc. Royal Soci., series A, Vol.269, pp.500 527, 1962.

21) Byerlee, D. : Brittle-ductile transition in rocks, Journal of Geophysical Research, p.4741, 1968.

22) Lambe, T.W. : A mechanistic picture of shear strength in clay, Res. Conf. Shear Strength Cohesive Soils, ASCE., pp. 555 580, 1970.

23) Schmertmann, J.H. : The shear behaviour of soils with constant structure, L. Bjerrum Memorial Volume, pp. 65 $\sim 98,1976$.

24）吉中竜之進・山辺 正：軟岩の変形特性について, 埼玉 大学建設系研究報告, No. 11, pp. 65 85, 1980.

25）寺師昌明・田中洋行ほか：石灰・セメント系安定処理土 の基本的特性に関する研究 (第 2 報)，港湾技術研究所報 告, Vol. 19, No. 1, pp. 33 62, 1980.

26）前川晴義・宮北 啓: 珠藻質軟岩の力学的特性, 土木学 会論文報告集, No. 334, pp. 135 143， 1983.

27）紫崎光弘ほか：薬液注入工法の設計と施工, 山海堂, p. 62 , 1977.

(1985.7. 16 · 受付) 